\title{
The development of a competitive private sector as the direction of the state anti-corruption strategy
}

\author{
Ph.D. Panzabekova A.Zh. aksanat@mail.ru \\ Deputy Director for International Co-operation and implementation \\ of the Institute of Economy MESб Almaty \\ Zhanbozova A.B. aksaulew@mail.ru \\ Centre for Social and Economic Research, Astana
}

The World's experience in the fight against corruption demonstratesthat several foreign countries have been able to createsuch mechanisms which allowed limiting the extent of corruptionso that it stopped to be a serious threat to normal performanceof the state machine. The practice of those states, where structuralchanges have given the greatest results and thereby created theground for successful economic growth, is of primary concern.According to Corruption Perceptions Index research for recentyears, the least corrupt countries in the world are Denmark, NewZealand, Finland, Sweden, Norway, Switzerland, Singapore, theNetherlands, Luxembourg, Canada, etc. These countries haveachieved some success in the fight against corruption. The idea of identifying the anti-corruption programs that have proventheir practical efficiency presents a great potential for positiveborrowing of foreign experience. However, it would be usefulto refer as well to experience of the younger countries, whichalso passed the stages of socioeconomic transformation, such asSouth Korea, Russia, Georgia etc. Besides that, anti-corruptionpolicy of the USA is also noteworthy. This research involves identifying the features of anti-corruption policies of foreign countries that enable them to successfully implement measures to combat corruption offenses, as well as clarify the ways in which certain experience of foreign legislation could borrow. It defines perspective ways of using foreign anti-corruption experience through establishment of a competitive private sector. The main factors that adversely affect the formation of bona fide competition in the private sector of the Republic of Kazakhstan, such as unreasonably high proportion of state involvement in the economy; the presence of "hidden monopolies"; high barriers to exit the market in monopolistic industries; administrative barriers; the absence of criminal liability of legal persons; underdevelopment of corporate management; passivity of business associations in the fight against corruption in the private sector. The authors have developed the recommendations, implementation of which is the destruction of naprvlena corruption networks, the development of bona fide competitive relations, increase transparency of corporate governance, enhance the fight against corruption on the part of the private sector, all of which will reduce the level of corruption risks. corruption risks.

Keywords: corruption, private sector monopoly, corporate management, criminal liability of legal persons.

DOI:10.17586/2310-1172-2016-9-4-57-64

\section{Развитие конкурентоспособного частного сектора как направление антикоррупционной стратегии государства}

\author{
Канд. экон. наук Панзабекова А.Ж. aksanat@mail.ru \\ Институт экономики МОН РК \\ 2. Алматы, Курмангазы ул., 29 \\ Жанбозова А.Б. aksaulew@mail.ru \\ Центр сочиально-экономических исследований - филиал РГКП «Институт экономики» \\ Комитета науки Министерства образования и науки Республики Казахстан в г. Астана \\ 010000, г. Астана, ул. Орпльколь 10/1, каб.303
}

\begin{abstract}
Мировой опыт борьбы с коррупцией свидетельствует о том, что в ряде зарубежсных стран удалось создать такие механизмы, которые позволили ограничить коррупцию маситабами, не представляющими серьезной опасности для нормального функционирования государственного аппарата. Особый интерес представляет практика тех государств, где структурные преобразования дали наибольшие результаты и тем самым создали предпосылки для успешного экономического роста. Согласно исследованиям Индекса восприятие коррупции за последние годы наименее коррумпированным государствами в мире являются Дания, Новая Зеландия, Финлянди, Швеция, Норвегия, Швейцария, Сингапур, Нидерланды, Люксембург, Канада и т.д. Эти страны достигли определенного успеха в борьбе с коррупцией. Идея вычленения
\end{abstract}


антикоррупционных программ, доказавиих на практике свою эффективность, представляет огромные перспективы для заимствования положительного зарубежного опыта. Однако сследует обратиться также к опыту более молодых стран, которые тоже проходили этапы социально-экономической трансформации, таких как, например Южнная Корея, Россия, Грузия и т.д. Заслуживает внимания и антикоррупционная политика США. Данное исследование предполагает выявление особенностей антикоррупционной политики зарубежных стран, которые позволяют им успешно осуцествлять мероприятия по борьбе с коррупционными преступлениями, а такље выяснения направлений, по которым определённый опыт зарубежнного законодательства можнно было бы заимствовать. В работе определены перспективные пути использования зарубежнног опыта противодействия коррупции посредством развития конкурентного частного сектора. Выявлены основные факторы, отрицательно влияющце на формирование добросовестных конкурентных отношений в частном секторе РК, к которым отнесены: необоснованно высокая доля государственного участия в экономике; наличие «скрытой монополии»; высокие барьеры выхода на рынок в монополистических отраслях; административные барьеры; отсутствие уголовной ответственности юридических лиц; неразвитость корпоративного менеджнмента; пассивность деловых ассоциаций в борьбе с коррупцией в частном секторе. Авторами разработаны рекомендации, реализация которых напрвлена на разрушение коррупционных сетей, развитию добросовестных конкурентных отношений, повыщение прозрачности корпоративного управления, активизацию борьбы с коррупцией со стороны частного бизнеса, что в совокупности приведет к снижению уровня коррупционных рисков.

Ключевые слова: коррупция, частный сектор, монополия, корпоративный менеджмент, уголовная ответственность юридических лиц.

Currently, society and the state have come to realize that the fight against corruption should not be limited to public administration reform and legal framework. Today, the effectiveness of anti-corruption strategy is increasingly determined by the system and the consistency of the taken measures.

However, to date there is no universal anti-corruption strategy. Private business can be a source of corruption, but often, especially in our conditions, is the victim of corruption. In the first case, private business carries bribery of public officials to establish a legal and regulatory environment in order to control the market. In the literature, this type of conduct is called "state capture" [1]. As a rule, monopoly companies are carried out this "state capture". In the second case, the private businesses, especially small and medium, are victims of raids, particularly prevalent in developing countries. There is a capture of the business through the use of bankruptcy corruption schemes, proceedings, acquisition of property, and falsification of documents, even before authorizing seizure of assets. This situation is quite difficult to solve, and requires some efforts from the state. Measures should be focused on the development of fair competition in the private sector.

At the same time the main focus should be on the elimination of the following reasons of lack of development of Kazakhstan competitive private sector:

1. Unreasonably high proportion of state involvement in the economy. The main part of the state property is characterized by large size, and they are usually concentrated in the natural resources sector and in the infrastructure sector. The consideration must be given to the negative experience of Kazakhstan in transition by the development of privatization policies. As is known, this process proceeded with manipulations and subterfuges by the influential officials to capture the lion's share of the economy in key industries. In many ways, the absence of an effective regulatory framework contributed to such situation. Therefore, the key is to develop well-constructed transparent denationalization policy. In our view, it would be appropriate to conduct the competitive restructuring of state-owned enterprises, which would lead to a reduction in opportunities for corruption offenses. In addition, in order to minimize the risks associated with the effect of unfair political framework, the antitrust and media structures should be involved in the process of implementation of the competitive restructuring.

2. The presence of "hidden monopoly." A variety of legal entities are operated with the participation of State in sectors with fixed competition. They have additional competitive advantages in the form of support of government agencies. Government agencies are increasingly creating subordinate organizations that exist because of budget programs. In addition, state authorities prefer to make government procurement by their "daughters". A large proportion of the amount allocated to state bodies on public procurement belongs to their subordinate agencies. [2] All these actions have led to the formation of "hidden" monopoly. To remedy this situation, should review the rules of the Law of the Republic of Kazakhstan "On state purchases", providing an opportunity to purchase for government agencies from one source of goods and services by the subordinate enterprises.

3. The high barriers to exit the market in monopoly industries. Decisions on de-monopolization of spheres of railway transportation, telecommunications, fuel and energy complex remain unfinished. The individual segments of the financial services market, including market infrastructure organizations of the stock market, continue to be monopolistic. In recent years Kazakhstan has taken significant steps to improve the antimonopoly legislation. However, the existing anti-trust legislation of Kazakhstan does not always require economic analysis of the involved relationships, forecasting the possible economic consequences of the use of certain standards. In paragraph 2 of Article 12 of the Law "On 
Competition" the position of the market entity is dominate, if its relevant market share is thirty-five percent or more [3]. This means that when the proportion is less than 35\% market share in fact cannot be recognized as such. In our view, the relationship between the size of the market share and competition is not always absolute, and conclusion about the presence or absence of the dominant position of the company, made solely on the basis of the concentration index, may not reflect the current market situation. It is possible to use a behavioral approach, which involves the determination of the company's ability to influence the market as a result of many factors analysis [4]. This approach is widely practiced in the US, EU, UK and other countries.

4. Administrative barriers. During the period of independence of Kazakhstan, in the absence of an appropriate legal framework, there was a rapid concentration of economic power, accompanied by corruption violations in the distribution of subsidies, grants, credits, and preferences in the country. For new entrants applied stringent administrative restrictions in the form of complex rules creation and registration of the enterprise; lack of access to credit; a complex system of permits and licenses, particularly for small businesses; frequent inspections by government authorities. All these administrative barriers were easily passable only through the "nepotism" or bribes. Only those enterprises flourished, which went to the meeting to the bribe-takers. Small and medium-sized enterprises, which have not been able to meet the demands of corrupt network, were stagnated.

Among other things, the inadequate leverage of property registration was used, which encouraged unclear ownership. But administrative barriers decreased significantly with the improvement of legislation in this area, with the introduction of requirements for disclosure of information about the financial position, holding the effective work of the bodies of registration and strengthening oversight of independent regulatory authorities, the introduction of e-government. However, the existence of the shadow economy confirms the indisputable fact of the need to carry out further work to reduce these barriers.

According to many experts, the existence of significant administrative barriers to doing business is forcing companies to circumvent them illegally. State loses twice, providing excessive administrative burden on business: waste for the maintenance of supervisory authorities - on the one hand, a decrease in the competitiveness of businesses - on the other [5]. Therefore, the great importance should have the simplification of administrative procedures, particularly in the field of tax and customs systems. However, the main efforts should be made to limit the personal contacts of officials and consumers, reducing the reporting forms and sanctions, a clear legal regulation of administrative procedures.

A gradual transition to a non-cash payment instruments is important also. To date, land issues are difficult to resolve in Kazakhstan. The competent authorities interact poorly with each other, due to location in different buildings. For any document or permit, the consumer has to spend a lot of time and efforts to bureaucratic procedures. Therefore, there is need for a detailed study of foreign experience to simplify the administrative procedures for land and permits obtaining.

5. The absence of criminal liability of legal persons. Institute of criminal liability already exists in many countries with different legal systems, like the US, UK, France, Finland, the Netherlands, Denmark, Scotland, China and Portugal. The Institute of quasi-head (administrative and criminal) liability of legal persons operates in Germany. Legal persons don't have criminal responsibility under the current Criminal Code of in Kazakhstan. The criminal liability introduction of legal persons for corruption offenses, including bribery and attempted bribery of public officials, and foreign officials will minimize opportunities for corruption. In our view, it is an effective mechanism for self-motivated legal entities to intensify the fight against corruption inside and outside the company.

6. Unethical behavior of the private sector because of the lack of development of corporate governance. It is believed that the private sector behavior is influenced by internal and external institutions. External institutions are aimed at ensuring the performance of contracts, rule of law and respect for property rights. For example, US law "On Counteracting the foreign corrupt practices" and the Law of the UK "Bribery" is determined that the large companies are legally responsible for the behavior of their suppliers and partners in global value chains. The operation of these laws is forced companies to select partners carefully, and to require adherence to anti-corruption behavior principles. Unfortunately, in Kazakhstan there are no legal documents, and therefore, it can be argued about the weak development of the external institutions, that regulate the behavior of private business.

Therefore, corporate governance and ethics play an important role in the fight against corruption in the private sector of the Republic of Kazakhstan.

In recent years, private business takes a lot of effort to eradicate corruption within the company and increasing the transparency of activities, also puts the same demands on its suppliers and partners. Usually the implementing good corporate governance is used as a measure, which is based on corporate ethics. Well-built corporate governance aims to hinder giving and receiving bribes, transparency and accountability. Corporate ethics determines the rules of conduct of managers and staff.

A unified approach to the applicability of moral principles in the world proclaims the Universal Declaration of Human Rights. Principles relating to the human rights are enshrined in the regulations on the ethics of business conduct. First of all, the Convention of the United Nations (UN) anti-corruption, the initiative of the World Economic Forum (WEF) "Partnership Against Corruption", the Organization for Economic Cooperation and Development (OECD) AntiBribery Convention of the OECD "On Combating Bribery of Foreign Public officials in international business 
transactions ", and other tough anticorruption legislations in some countries like current "Act of corruption abroad" in the USA [6].

Without belittling the importance of the role of the aforementioned documents in the fight against bribery and to ensure fair competition, the difficulties in the implementation of their principles into practice should not be left unmentioned. The most important issue is ensuring not only the national and international commitments on anticorruption, but also appeals to the leadership of the struggle against bribery.

The expected accession of Kazakhstan to the World Trade Network (WTO) imposes obligations on the country to comply with a set of rules that promote fair competition. These rules consist of provisions aimed at harmonizing business and government relations, the transition from protection to greater transparency and impartiality in order to prevent discrimination in trade. Such circumstances necessitate revision of the behavior of entrepreneurs. In this context, effective corporate governance and ethical business conduct can have a beneficial effect on the company's competitiveness and attractiveness for investors.

However, the private sector of Kazakhstan's commitment to maintain the highest ethical standards only on paper, but in reality their behavior can be called corrupt. According to the results of the WEF survey among residents of the Republic of Kazakhstan in the framework of the rating of global competitiveness in 2014, $16.7 \%$ of respondents believe that corruption is the most serious barrier to doing business. [7] In fact, corruption prevents the conduct of business, the development of fair competitive relations on the market. This relationship is confirmed by international evidence (Table 1). As the table shows, the higher is the corruption perception index, the higher is the country's competitiveness, and - on the contrary.

Table 1

Comparison of ratings of global competitiveness and the perception of corruption in 2014

\begin{tabular}{|l|c|c|}
\hline \multicolumn{1}{|c|}{ Country } & $\begin{array}{c}\text { Corruption Perceptions } \\
\text { Index in 2014 }\end{array}$ & $\begin{array}{c}\text { The Global Competitiveness } \\
\text { Index in 2014 }\end{array}$ \\
\hline Finland & 89 & 5,5 \\
\hline Norway & 86 & 5,4 \\
\hline Singapore & 84 & 5,6 \\
\hline United Kingdom & 78 & 5,4 \\
\hline Japan & 76 & 5,5 \\
\hline USA & 74 & 5,5 \\
\hline Malaysia & 52 & 5,2 \\
\hline Italy & 43 & 4,4 \\
\hline Morocco & 39 & 4,2 \\
\hline India & 38 & 4,2 \\
\hline China & 36 & 4,9 \\
\hline Kazakhstan & 29 & 4,4 \\
\hline Russia & 27 & 4,4 \\
\hline Tajikistan & 23 & 3,9 \\
\hline Yemen & 19 & 3,0 \\
\hline Sources: $[7,8]$ & & \\
\hline
\end{tabular}

Despite not rosy position of Kazakhstan in the world ranking of perceptions of corruption, the preconditions for change are growing. In addition to adopting a new law on corruption, the government entered into the EAEC. It does not mean that the impact of anti-corruption strategy will increase instantly. Kazakhstan's next step should be the country's accession to the OECD Convention on Bribery, which prohibits bribery of foreigners at the conclusion of international agreements. Ratification of the Convention will require making some adjustments to the legislation of Kazakhstan in the field of anti-corruption policy, as the Convention requires incurred criminal liability for bribery to foreign officials.

There are many different factors that companies should consider when developing their own code of ethics within the general guidelines on corporate governance. These include laws and regulations of countries in which the companies operate, as well as international conventions such as the OECD Principles of Corporate Governance. Also the Concept of corporate social responsibility and corporate citizenship plays an important role in stimulating the development of corporate governance and the development of codes of business ethics [9]. In this case the formation of business ethics requires a distinction between norms and values in the first place. The rules set specific rules, which cannot be violated.

Every company needs to develop a clear scheme of monitoring for breach of the rules by employees. In this case the «Principles for Countering Bribery in Business» can be useful, developed jointly with Transparency International Social Accountability International. This guide provides clear instructions for building a system of anti-corruption [10]. 
As part of building an effective business ethics in order to counter bribery, Thailand has shown good results - more than a hundred Thai companies adopted the uniform anti-corruption code of conduct voluntarily, which has been certified by external auditors.

Building ethical organizations includes: compliance with regulatory standards, the implementation of an integrated program of ethical standards; development of new standards and standards of business ethics.

The authors have developed an exemplary diagram illustrating the construction of an ethical organization in three phases (Figure 1). The proposed scheme is based on international guidelines and regulations, and does not determine the sequence of development stages of corporate ethics, most likely it can be used as a model taking into account the characteristics and the type of company.

Of course, the effectiveness of ethical standards depends on the size of the company. Consider that companies with small resource level are inferior to transnational corporations for ensuring regulatory compliance; it can be argued that uniform standards of corporate governance do not exist.

At present, some countries have developed codes of corporate governance for SMEs, corporations, national companies. «Principles for Countering Bribery in Business» in 2008 were replenished by special edition for small and medium-sized enterprises.

Therefore, international experts proposed solutions should be adapted to the company's size, time constraints and the local conditions. However, we must understand that the international and national regulators do not show their effectiveness, while the companies do not want to fight bribery themselves.

For the private business purposefully functioning is necessary as well as seeking for the methods of improvement of their ethical standards.

Good corporate governance, business ethics should not be perceived only as a global document and should be used as a guide and help to build their serious norms and standards of ethics and corporate governance. Only two-way control, systematic approach will ensure that corruption within the company or the industry has become the exception rather than the rule.

As a result Conference Board research, conducted among companies around the world to study the development of business ethics, $10 \%$ of respondents noted the important role of the Board of Directors [11].

Also, the research notes that above all the increased role of the Board of Directors brings to increase of prosecutions after adoption of the Laws «On countering foreign corrupt practices» «On the reform of Wall Street and Consumer Protection». Also, after the amendments and changes in the Federal Sentencing Guidelines 2004 in the United States, in terms of increasing the responsibility of legal entities, the boards of directors of companies have been forced to take responsibility for enforcement officer's ethical requirements to reduce the risk of bringing liability of the legal entity.

The Guidelines clearly states that companies with an effective program of regulatory compliance for the prevention and detection of criminal conduct, in the case of prosecution for violation of the Law «On countering foreign corrupt practices» will be eligible for a reduced sentence, as well as a significant decrease sanctions and fines up to 10 times. Such motivational mechanisms encourage companies to improve business ethics directed at the eradication of corruption offenses. Therefore, at the present stage of development of Kazakhstan introduction of such regulations is very timely and appropriate. According to the Guidelines, the program regulatory compliance should be based on the following 10 provisions [12]:

1. Availability of written standards and procedures to detect and prevent criminal behavior.

2. Strengthening of the Board of Directors responsibility to ensure regulatory compliance and adherence to business ethics.

3. Securing the responsible senior officials to ensure regulatory compliance. 


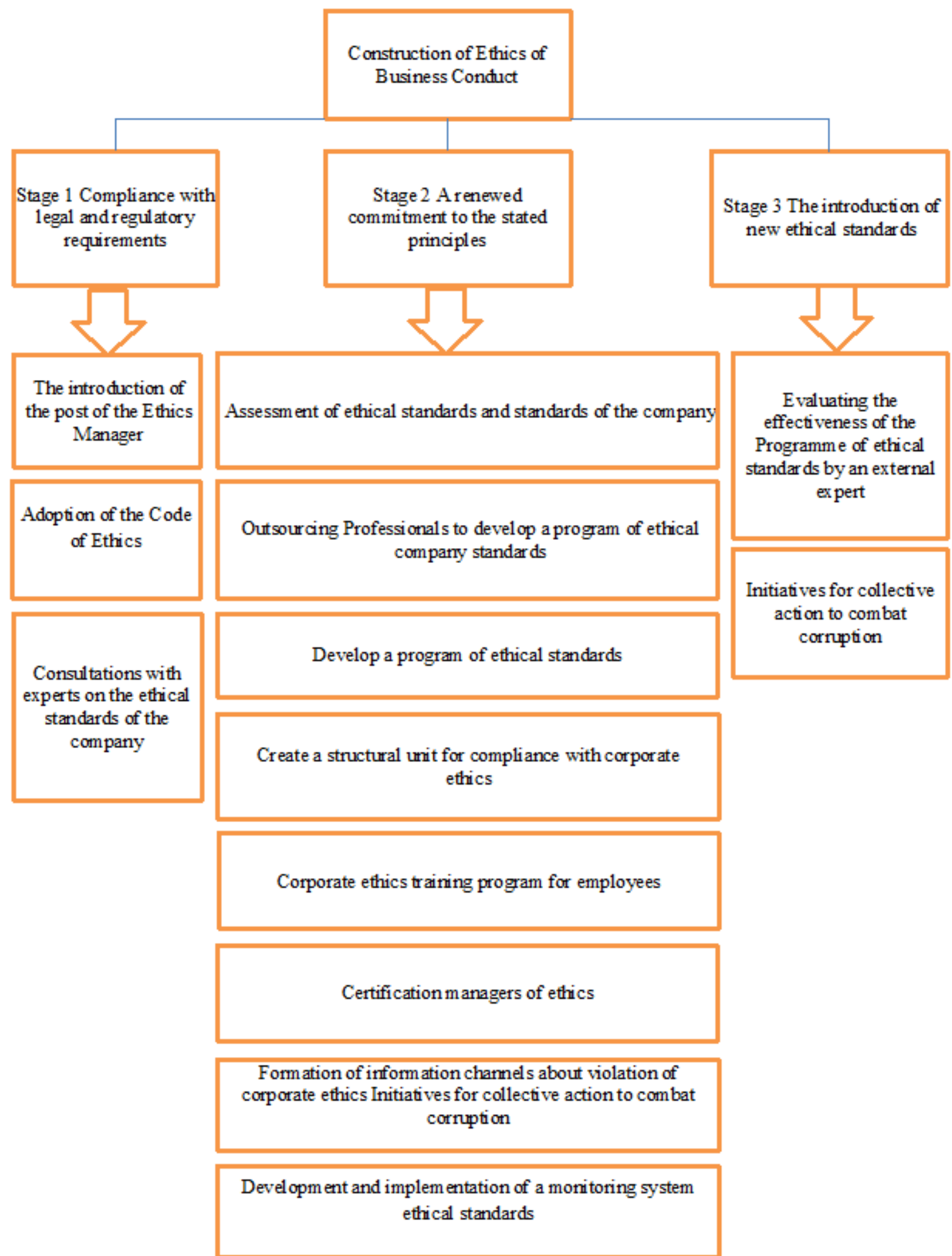

Figure 1. Stages of formation and development of an ethical culture

4. The imposition of the current work responsibility on the heads of structural divisions with the obligation of periodic accountability to the board.

5. The tightening of administrative measures against employees who do not comply and violate the ethical standards of the company, up to and including dismissal. The adequate verification of potential employees on the propensity to taking bribes and other corruption offenses.

6. The introduction of periodical education system standards and procedures for regulatory compliance. 
7. Control over the execution of the program to ensure regulatory compliance and ethics. Regular monitoring offenses, including corruption and crime. The introduction of anonymous reporting system for such violations. Evaluating the effectiveness of the company with regard to ensuring compliance with ethical standards.

8. The introduction of incentives to ensure the execution of the program.

9. Quick and adequate response to the facts of criminal behavior and the adoption of appropriate measures to prevent the recurrence of similar cases.

10. Improving the functioning of the program on the basis of periodic assessment of the risks of corruption offenses. United Kingdom, following the positive experience of the United States, issued a guide to the law «On Combating Bribery» [13], which describes the detailed procedure to deal with bribes. The document envisages the laying of responsibility on the board of directors of «organizational culture without bribery.

In addition, the UK Office for the fight against fraud in especially large sizes has developed a unified manual for prosecutors, which establishes the cases when the law provides for the prosecution. According to management, the company, having appropriate procedures, will have the added benefit of mitigation of punishment in case of violation of the law «On Combating Bribery».

In other developed countries, where there are no such manuals and guides to laws on bribery, the Boards of Directors are the initiators of the establishment of similar anti-corruption standards, procedures, ethics training programs for employees and require compliance with ethical rules, even from suppliers. All this is due to the trend of modern times, when the companies are interested themselves in improving and maintaining the reputation and profits increase, attracting large investors [14]. But, unfortunately, this trend became widespread only in the developed market structures. In Kazakhstan conditions is expedient to implement the effective mechanisms, pushing and forcing the companies to standardize the system of corporate governance to minimize corruption crimes as in the US and the UK.

7. The passivity of business associations in the fight against corruption in the private sector. Today in the world there is a growing role of business associations in the implementation and development of ethical standards for its member companies. For example, in Russia at the end of 2012 four of the largest business associations have adopted the Anti-Corruption Charter of Russian business with the exacting standards of compliance, which is aimed at improving the investment climate. 371 participants, signatories to this Charter, are required to avoid bribing foreign officials and to carry out strict control of compliance [15]. Following this experience, it is necessary to consider the adoption of the Code of Conduct at the level of business associations in Kazakhstan, with the mandatory inclusion of standards and regulations prohibiting bribery. The legislation does not prevent the business associations in making such documents.

Also it is essential to increase the rights of business associations in the development of law or program, relating to the creation of favorable conditions for business. As the experience of many developed countries, in the countries where business associations represent the views and interests of the companies, the possibility of state capture and administrative corruption is close to zero.

Thus, an important component of the anti-corruption strategy is the development of competitive private sector with the aim of destroying the structural links that increase the likelihood of corruption offenses. Measures should be focused on:

1. Reducing government involvement in business. It is important to conduct a competitive restructuring of stateowned enterprises, which would lead to a reduction in opportunities for corruption offenses. Also it is necessary to ensure mandatory participation of antitrust agencies and the media in the process for addressing the risks associated with the effect of unfair political structures.

2. Avoidance of "hidden monopolies" by revising the provisions of the Law of the Republic of Kazakhstan "On state purchases", providing an opportunity to purchase for government agencies from a single source of goods and services by the subordinate enterprises.

3. The introduction of criminal liability of legal persons. Firstly, it is needed to make changes in the Criminal Code of RK in regard to liability of legal persons for "money laundering", evasion of tax payments, corruption offenses, bribery and other criminal acts. Also it is necessary to devise ways of implementation and possible forms of punishments used by entities when bringing them to justice and to include them in the respective legislative and regulatory documents of concern spheres. Implementation of these measures will enhance the liability of legal persons in the fight against corruption.

4. Accession of Kazakhstan to the OECD Anti-Bribery Convention. This document puts a ban on bribing foreigners at the conclusion of international agreements, and assumes the criminal liability of legal persons in case of violation of this prohibition.

5. The introduction of instruments to encourage companies to standardize the system of corporate governance for minimization of corruption crimes. One of such effective instruments may be the development and implementation of guidelines or manuals to the law on corruption. The guide should be covered by the principles on which it will be possible to assess the effectiveness of regulatory compliance with business ethics, as an exemplary guide on the construction of business ethics organization, in which all the elements, indicated in Figure 1, must be presented. In this case, the conditions need to be clearly defined, where a legal person, held liable, may be eligible for commutation in the form of 
exemption from a considerable part of the fines, etc. An effective program of regulatory compliance for the prevention and detection of criminal behavior can be designated as these conditions. This practice is applied in the US and the UK.

6. Increase the rights of business associations in the development of a law or program relating to the creation of favorable conditions for business, fight against bribery, corruption and other criminal activities in the field of business.

The implementation of the above proposed measures will contribute to the destruction of the corrupt networks, development of fair competition relations, increase transparency of corporate governance, strengthen the fight against corruption on the part of the private sector, all of which will reduce the level of corruption risks.

\section{Bibliography}

1 World Bank report. The fight against corruption in the transitional period [Electronic resource] Access mode: http:// www.worldbank.org. (accessed date 22.05.2015).

2 Gudenko L. Quasi-public structures still exist. http:// www.newregion.kz/ (accessed date 13.02.2015).

3 The Law of the Republic of Kazakhstan dated December 25, 2008 № 112-IV “On Competition”. Kazakhstanskaya Pravda, December 30, 2008 N 294-295 (25741-25742).

4 Shimshikov Z.E., Utibaev B.S. The Customs Union of Kazakhstan and exit conditions of monopoly on the world market// old.group-global.org/ru/storage_manage/download_file/20258.

5 Формирование и развитие конкурентных факторов экономики Республики Казахстан / Под ред. Шимшикова Ж.E. - Астана: Центр социально-экономических исследований - филиал РГКП «Институт экономики» КН MOH PK, 2013.

6 The Fight against Corruption: Theory and Practice: multi-authored monograph. / Edited by A.A.Satybaldin, A.Zh. Panzabekova - Vienna, Austria: Association for Advanced Studies and Higher Education"East West". - 2016. - 204 pgs.

7 The Global Competitiveness Report 2014-2015 [Electronic source] Access mode: http://www.weforum.org/issues/ global-competitiveness (accessed date 28.05.2015).

8 The Corruption Perceptions Index 2014 [Electronic source] Access mode: http://cpi.transparency.org/ date treatment 28.05.2015).

9 Панзабекова А.Ж., Альжанова Ф.Г., Халитова М.М., Рузанов Р.М., Турсынбаева Д.К. Коррупция: основные тенденции противодействия. Коллективная монография [под ред. Л.А. Андреевой]. Новосибирск: Изд. «Сибак», 2015. - 196 с.

10 The Business Principles for Countering Bribery [Electronic source] Access mode: http://www.transparency.org/whatwedo/tools/business_principles_for_countering_bribery (accessed date 25.05.2015).

11 Ronald E. Berenbeim. Ethics Issues and Programs: The Role of the Board. The Conference Board, NewYork. 2010. 198

12 Richard L. Cassin. Ten Elements of an Effective Compliance Program, FCPA Blog, Oct 22, 2007 [Electronic source] Access mode: http://www.fcpablog.com/blog/2007/10/22/tenelements-of-an-effective-compliance-program.html (accessed date 15.02.2015г.).

13 The Bribery Act 2010 Guidance, [Electronic source] Access mode: http://www.justice.gov.uk/downloads/legislation/ bribery-act-2010-guidance.pdf (accessed date 15.03.2015г.).

14 Kaufmann, Daniel, AartKray, Massimo Mastruzzi. Governance Matters IV: Governance Indicators for 1996-2004, World Bank Policy Research Working Paper No. WPS 3630, 2005.

15 Anti-Corruption Charter of Russian Business [Electronic source] Access mode: http://against-corruption.ru/ru (accessed date 13.05.2015). 